\title{
RETURN TO WORK AFTER SPINAL FRACTURE SURGERY: AN ANALYSIS OF PREDICTIVE FACTORS
}

\author{
RETORNO AO TRABALHO APÓS FRATURA CIRÚRGICA DE COLUNA: UMA ANÁLISE \\ DOS FATORES PREDITIVOS
}

\section{RETORNO AL TRABAJO DESPUÉS DE CIRUGÍA POR FRACTURA DE COLUMNA: UN ANÁLISIS DE LOS FACTORES PREDICTIVOS} \author{
Xavier Soler I Graells ${ }^{3}$ \\ 1. Hospital de Clínicas e Hospital do Trabalhador (UFPR), Curitiba, Paraná, PR, Brazil. \\ 2. Hospital do Trabalhador, Curitiba, Paraná, PR, Brazil. \\ 3. Hospital de Clínicas (UFPR), Curitiba, Paraná, PR, Brazil.
}

Guilherme Schlusaz Morais ${ }^{1}$, Marcel luiz Benatoํㅜ, Álynson Larocca Kulcheski², Pedro Grein Del Santoro², André Luís Sebben ${ }^{1}$

\begin{abstract}
Objective: To retrospectively evaluate factors that influence the return to work of patients of economically active age submitted to surgery due to spinal fractures. Methods: Patients aged between 18 and 65 years that underwent surgery after spinal fracture from 2012 to 2014 were selected. Through a specific questionnaire and review of the medical records, we identified factors that may have influenced the labor return of these patients. Results: Initially, 114 patients were allocated. After applying the inclusion criteria, 51 patients remained. Age, schooling, time to sit on the bed, and residual pain were the factors that influenced all outcomes. Other variables such as ISS (Injury Severity Score), segment of spine, number of affected vertebrae, associated lesions, and previous employment regimen had no influence. Conclusions: The rate of return to work after being submitted to surgery due to a fracture of the spine is related to age, schooling, residual pain, length of hospital stay, and the time the patient takes to be able to sit alone postoperatively. Physiotherapy positively influences the patient's self-assessment regarding the ability to perform basic tasks. These variables can be used to identify a possible difficulty in the reallocation of these patients in the labor market.
\end{abstract}

Keywords: Spine; Spinal fractures; Spinal injuries; Treatment outcome; Employment, supported; Rehabilitation; Activities of daily living.

\section{RESUMO}

Objetivo: Avaliar retrospectivamente fatores que influenciaram o retorno ao trabalho de pacientes em idade economicamente ativa submetidos a cirurgias por fratura de coluna. Métodos: Foram selecionados pacientes com idade entre 18 e 65 anos submetidos à cirurgia depois de fratura de coluna de 2012 a 2014. Por meio de questionário específico e revisão dos prontuários, identificamos fatores que podem ter influenciado o retorno laboral desses pacientes. Resultados: Foram alocados inicialmente 114 pacientes. Após aplicação dos critérios de inclusão, restaram 51 pacientes. Idade, escolaridade, tempo para sentar no leito e dor residual foram os fatores que influenciaram todos os desfechos. Outras variáveis como ISS (Injury Severity Score), segmento da coluna, número de vértebras afetadas, lesões associadas e regime de emprego prévio não tiveram influência. Conclusões: A taxa de retorno ao trabalho após ser submetido à cirurgia devido a uma fratura de coluna tem relação com idade, escolaridade, dor residual, tempo de internação e com o tempo que o paciente demora em conseguir sentar sozinho no pós-operatório. A fisioterapia influencia positivamente a autoavaliação do paciente com relação a sua capacidade de realizar tarefas básicas. Essas variáveis podem ser usadas para identificar possíveis dificuldades na realocação desses pacientes no mercado de trabalho.

Descritores: Coluna vertebral; Fraturas da coluna vertebral; Traumatismos da coluna vertebral; Resultado de tratamento; Readaptação ao emprego; Reabilitação; Atividades cotidianas.

\section{RESUMEN}

Objetivo: Evaluar retrospectivamente los factores que influenciaron en el retorno al trabajo de pacientes en edad económicamente activa sometidos a cirugías por fractura de columna vertebral. Métodos: Se seleccionaron pacientes con edad entre 18 y 65 años sometidos a la cirugía después de fractura de la columna vertebral de 2012 a 2014. Por medio de un cuestionario específico y revisión de los registros médicos, se identificaron factores que pueden haber influenciado el retorno laboral de esos pacientes. Resultados: Se asignaron inicialmente 114 pacientes. Tras la aplicación de los criterios de inclusión, quedaron 51 pacientes. La edad, la escolaridad, el tiempo para sentarse en el lecho y el dolor residual fueron los factores que influenciaron todos los resultados. Otras variables como ISS (Injury Severity Score), segmento de la columna, número de vértebras afectadas, lesiones asociadas y régimen de empleo anterior no tuvieron influencia. Conclusiones: La tasa de retorno al trabajo después de someterse a cirugía debido a una fractura de la columna vertebral tiene relación con edad, escolaridad, dolor residual, duración de la estancia hospitalaria y con el tiempo que el paciente tarda en conseguir sentar solo en el postoperatorio. La fisioterapia influye positivamente en el autoevaluación del paciente con respecto a su capacidad para realizar tareas básicas. Estas variables pueden ser utilizadas para identificar posibles dificultades en la reasignación de estos pacientes en el mercado de trabajo.

Descriptores: Columna vertebral; Fracturas de la columna vertebral; Traumatismos vertebrales; Resultado del tratamiento; Empleos subvencionados; Rehabilitación; Actividades cotidianas. 


\section{INTRODUCTION}

The number of patients who are victims of spinal trauma seeking care at emergency services is growing. In many cases, these injuries leave the patient, the family, and society itself with irreversible sequelae and mortality rates are also significant. Spinal traumas are common and diverse. Their severity can range from a simple wedging fracture to a serious fracture-luxation and, clinically, we may be confronted with patients without any neurological involvement or involvement of other organs or patients with spinal cord lesions and multiple systemic injuries. ${ }^{1}$

Saboe et al. $^{2}$ reported that associated lesions occur in $47 \%$ of the cases of spinal fractures, involving the skull in $26 \%$ of cases, the chest in $24 \%$, and the long bones in $23 \%$. Abdominal lesions occur in very few cases and, generally, result from car accidents and are associated with fractures at several vertebral levels. ${ }^{3,4}$ It is estimated that $5 \%$ of patients with cranioencephalic trauma (CET) also present spinal lesions and, reciprocally, $25 \%$ of patients with spinal trauma have at least mild $\mathrm{CET}^{5}$

Montesano and Benson pointed out that the most frequent cause of spinal lesions are motor vehicle accidents (45\%), followed by falls from heights $(20 \%)$, sports accidents $(15 \%)$, and acts of violence (15\%), but they highlighted that falls are responsible for $70 \%$ of vertebral fractures in patients in the 75 years and up age group. ${ }^{6}$

The rates of neurological lesions associated with spinal fractures are widely known in the literature, ranging from 20 to $40 \%$ of cases. ${ }^{7}$

Victims of spinal trauma are typically young men of economically active age, ${ }^{8}$ who, due to the trauma, face extensive and expensive hospital treatment, followed by new professional, financial, and emotional difficulties. ${ }^{9}$ Due to the severity of the trauma, these patients many times may evolve with unfavorable outcomes, with chronic pain, functional deficit, and the inability to return to work or study. ${ }^{10}$

Once they undergo surgery, these patients expect some degree of recovery and they want to return to work and their previous activities. ${ }^{11}$

There is little information available in the literature about predictive factors of return to work or in relation to adaptation to new job functions. Studies that examine predictors of return are characterized by several limitations, usually targeting victims with spinal cord lesions or being limited to specific populations and few modifiable factors. ${ }^{11-13}$

This study addresses this knowledge gap, presenting an analysis of the factors that predict poor outcomes, attempting to identify them and relate them to return to work and to a subjective assessment of the functional capacity of patients with spinal fractures. These results will assist multidisciplinary teams to identify individuals at risk and then promote health and specific care actions to improve their prognoses.

\section{METHODS}

This was an epidemiological, longitudinal, retrospective cohort study. It was approved by the Institutional Review Board of the Hospital do Trabalhador - UFPR, as opinion number 1.211.217. The selected patients who satisfied the inclusion criteria and who agreed to participate in the study were offered an informed consent form, which they signed in agreement.

The inclusion criteria were patients between 18 and 65 years of age, who were working regularly during the 30 days prior to the accident and who presented surgical spinal fractures. All of them underwent surgery at the Hospital do Trabalhador da Universidade Federal do Paraná during the period from January 1 to December 31,2012 . The surgeries were performed by a team of four orthopedic surgeons, specialized in spinal surgery and with extensive experience in the treatment of these injuries. To enable a comparison between the results, patients with prior neurological sequelae or those suffered in the accident, patients who were permanently dismissed from work by the INSS or because unable to work due to other systemic injuries unrelated to the spine, patients who were lost during outpatient clinic follow-up, patients who refused to sign the informed consent form, and those who died were excluded.

Twelve months after the spinal surgery procedure, a questionnaire was applied to find out what factors might have influenced a return to work. Epidemiological factors, such as age, sex, education level, formal/informal work, employee/self-employed, and comorbidities were evaluated. Factors related to the trauma, such as rehabilitation, days in the hospital, days in the ICU, associated injuries, spinal segment(s) fractured, number of fractured vertebrae, presence of postoperative complications, preoperative and residual visual pain scale (VAS), and the time following surgery to sit up alone in the bed.

Using the data from the review of the medical records, the Injury Severity Score (ISS), which is a trauma index based on a graded anatomical system that provides an overall score for patients with multiple injuries, was calculated for each patient. Each injured region of the body received a determined number of points depending on severity. The scores of the three regions of the body with the most serious wounds were squared and summed to produce the ISS score. This score can range from one to 75 and the higher the score, the more serious the trauma. ${ }^{14}$

In terms of the clinical outcome, the time away from work after surgery, the ability to return to the same prior work activity, the possibility of performed daily activities, residual pain (VAS), and the subjective evaluation of the patient concerning their work capacity and adaptation to a new function.

The patients selected for the study were divided into groups and evaluated as follows:

\begin{tabular}{|c|}
\hline Returned to work $x$ Did not return to work \\
Considers themselves able to work $x$ Does not consider \\
themselves able to work \\
Considers themselves able to perform daily activities $\times$ Does not \\
consider themselves able to perform daily activities \\
Adapted to another work function $\times$ Did not adapt
\end{tabular}

For the statistical analysis, we used regression analysis and the chi-squared, Fisher's exact, and Mann-Whitney tests, given the number and type of variables to be compared. We considered values of $p<0.05$ to be significant.

\section{RESULTS}

Initially, 114 patients were selected for the study. Of these, 51 satisfied the inclusion criteria, whose results are presented below. Age: The average age was 40 years, ranging from 18 to 59 years of age. The statistical analysis showed that this factor influences all the outcomes. Younger patients returned more often to work $(p=0.004)$ and rated themselves more able to perform work activities $(p=0.013)$ and basic day-to-day activities (0.007). These patients, when required, were able to adapt to other functions with a higher success rate than older patients $(p=0.026)$.

Education level: Most individuals in the sample had completed high school (37.5\%), followed by elementary school completed (35.4\%), elementary school not completed or illiterate (16.6\%), with the minority $(8.44 \%)$ graduated from college. (Figure 1)

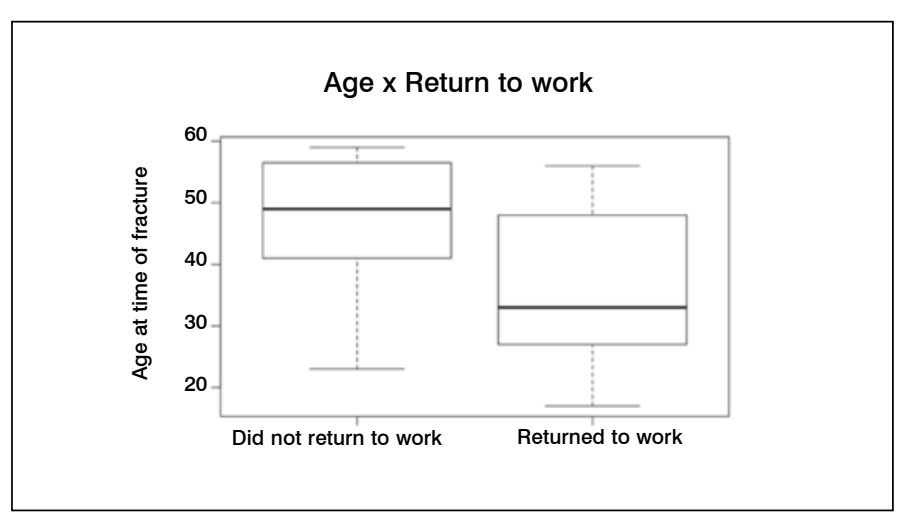

Figure 1. Relationship between the average ages of patients who did not return to work (left) and those who returned to work (right). 
The education level was directly proportional to the rate of return to work ( $p=0.005)$, the ability to perform daily activities $(p<0.016)$, and to professional adaptation and personal judgment of the ability to return to work $(p<0.005)$. (Figure 2$)$

Patient characteristics (sex, comorbidities, and back pain prior to the trauma): As regards sex, the distribution was $72.5 \%$ men and $27.5 \%$ women. There were no comorbidities in $81.25 \%$ of the patients and $22.9 \%$ reported back pain prior to the fracture (average VAS 4.2). There was no statistically significant difference between the outcomes of the groups in terms of these variables.

Time following surgery to sit up alone in bed: the time that a patient takes to be able to achieve a sitting position in bed without assistance was a predictive factor of capacity to return to work, to perform basic day-to-day tasks, and to consider themselves able to perform those activities, with a $p<0.005$

Days in the hospital: patients who spent more time in the hospital had lower rates of return to work $(p=0.04256)$. This factor, however, did not have the same influence on the other endpoints.

Residual spinal pain: postoperative pain is a determining factor for both return to work and patient self-evaluation regarding their work capacity $(p<0.0001)$. (Figure 3$)$

Characteristics of the trauma and the fracture (ISS, spinal segment(s) fractures, number of fractured vertebrae, associated injuries, in-hospital complications, and days in the ICU): The ISS was 10.25, ranging from four to 36 . On average, 1.54 vertebrae were fractured per patient, ranging from one to five. Half of the fractures were in the lumbosacral segment, $27 \%$ in the thoracic, $12.5 \%$ in the cervical, and $10.5 \%$ in multiple segments. Half of the patients had injuries associated with other regions of the body. Sixteen percent (16\%) of the patients were in the ICU, ranging from two to 60 days. None of these factors had any statistically significant influence on the results.

Work regime (self-employed or employed, formal or informal): In our sample, $81.25 \%$ of the patients were employees with work

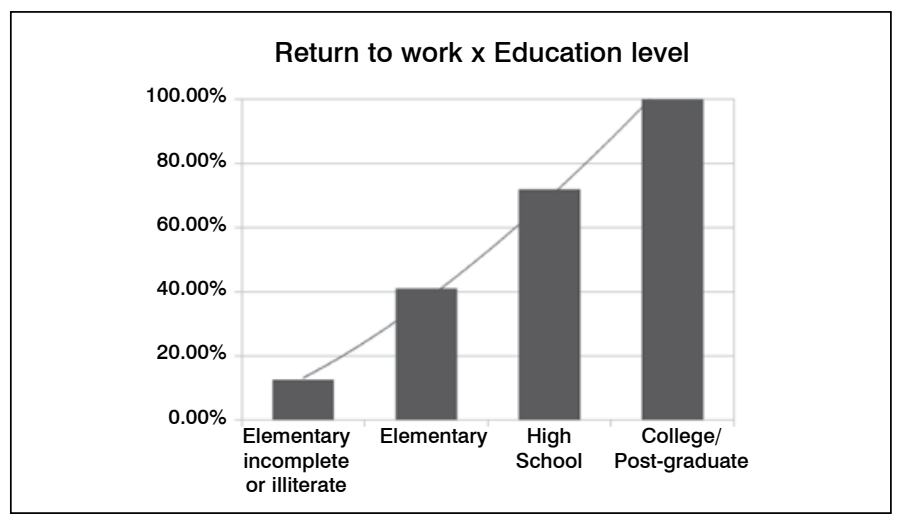

Figure 2. Relationship between education level and rate of return to work following surgery.

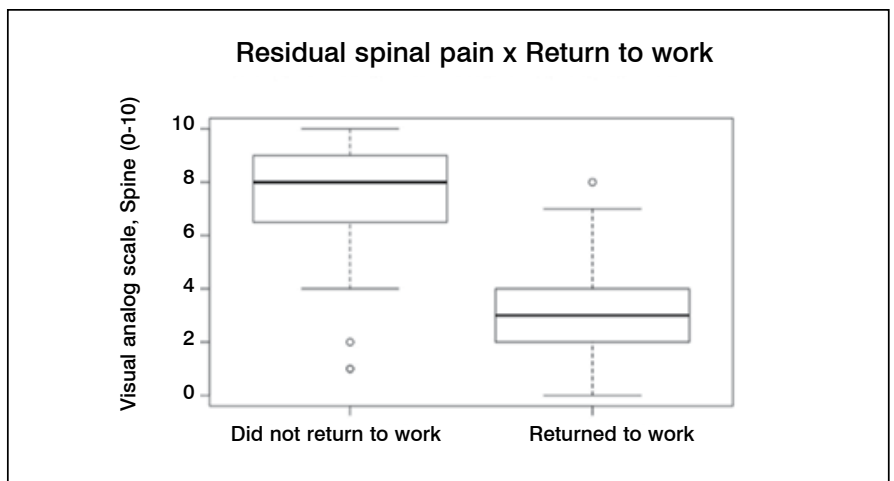

Figure 3. Relationship between residual pain and rate of return to work activities. contracts when they suffered the fracture and $18.75 \%$ worked in an informal regime, while $43.75 \%$ were self-employed and $55.25 \%$ were employees. None of these variables impacted the outcomes studied. (Figure 4)

Physical therapy: the patients attended, on average, 17 physical therapy sessions, ranging from 0 to 50 . The number of sessions and participation or not in physical therapy did not change the rate of return to work $(p=0.4)$, but it positively influenced $(p=0.0394)$ patients' self-evaluation of their capacity to perform day-to-day activities. (Figure 5)

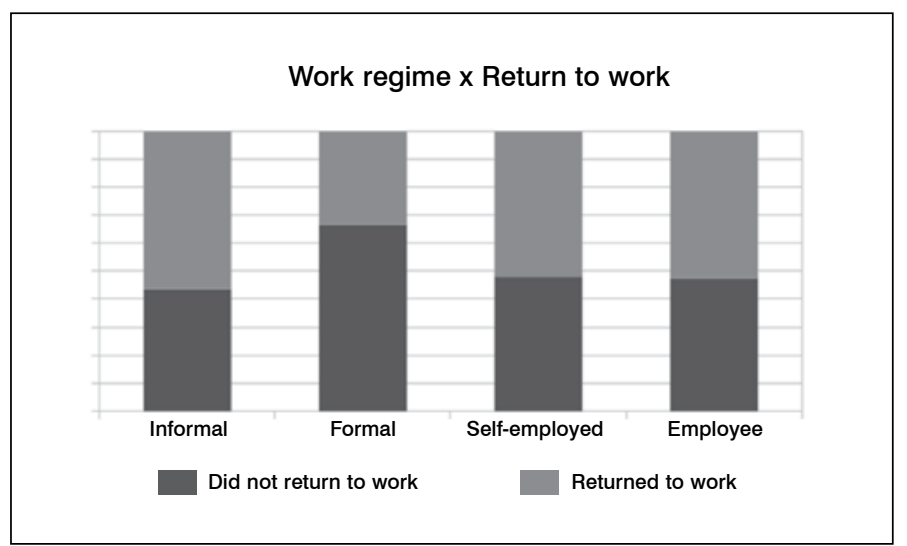

Figure 4. Distribution of the patients by work regime and return to work.

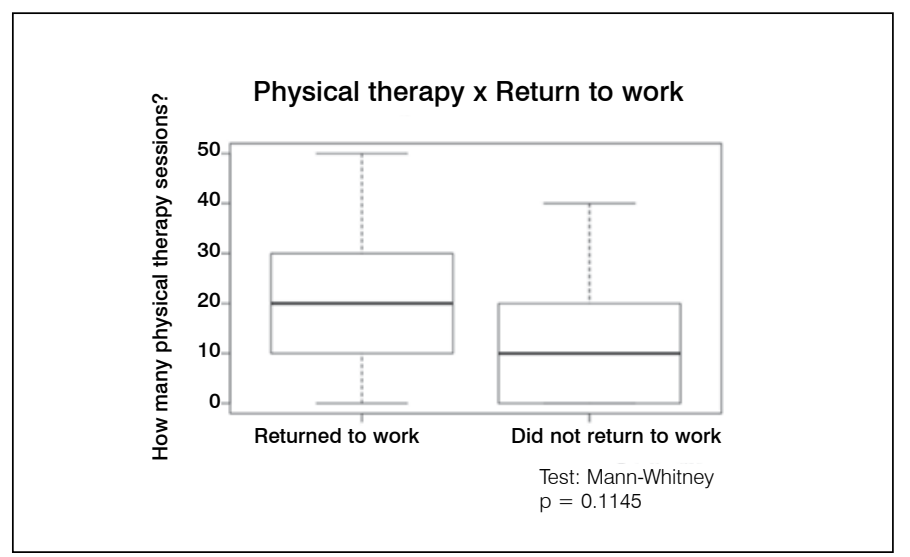

Figure 5. Relationship between the number of physical therapy sessions and the rate of return to work.

\section{DISCUSSION}

Little is known about predictive factors of return to work 12 months following surgical treatment for traumatic spine fractures without neurological deficit. ${ }^{15}$

This was a retrospective cohort study that sought to identify factors that influence return to work in patients with surgical spinal fractures. In our sample, $50 \%$ of the patients were considered to be limited functionally and $52.08 \%$ of the patients returned to the same type of employment they had prior to the trauma. In similar studies found in the literature, the rate of functional limitation was similar at $56 \%{ }^{16,17}$ Return to work was higher in the literature, ranging from 70 to $94 \% .{ }^{16}$ Some hypotheses may explain this discrepancy: differences in the education level and in the ability of the labor system in the country where the study was conducted to reintegrate these patients.

In our study, only surgical cases were included because we understood that, being patients who underwent major intervention by the hospital team, they presented more modifiable factors that could improve their results. However, the study demonstrated that the factors with the greatest influence are factors that are inherent to the patient: age and education level. By 1988, Mackenzie et al. ${ }^{17}$ had already identified the importance of these factors in post-traumatic 
functional recovery, and the sample corroborates and validates this association for our population.

We also observed two possible predictors of difficulty in returning to work: time to be able to sit up alone in bed and length of hospitalization. The literature shows that longer hospitalizations are related to more difficulty in returning to work, ${ }^{18}$ while we found no similar studies about the time to be able to sit up in bed. These findings serve as warning signals of a possibly unfavorable outcome to the surgeon and the multidisciplinary teams.

Physical therapy did not change the rates of return to work, but made the patients judge themselves to be "more capable" and less limited. To interpret these findings, we must understand that the functional rehabilitation of the patient - the ability to perform their daily life activities - differs from social and workforce reintegration the capacity of the environment to reintegrate that individual. Thus, adequate rehabilitation is essential and should be encouraged, however, the patient's overall results in terms of return to their previous functions does not depend solely on it.

It is noteworthy that the previous work regime of the patient had no influence on results. Thus, the sample did not support the hypothesis that the informal and self-employed worker would have better results than the formal employee. Residual pain was directly related to functional limitation and to not returning to work, which we expected and was already demonstrated in previous studies. ${ }^{15}$ We showed that there was no significant influence from secondary labor gain on the outcome of spinal fractures in the sample studies, but that there was influence from physiological factors, like pain, and factors inherent to the individual's capacity for adaptation, like age and education level. The literature also shows that these last three factors are predictive of worse outcomes in relation to return to work. ${ }^{17-19}$

\section{CONCLUSIONS}

The rate of return to work after surgery for a spinal fracture is closely related to the age and education level of the patient. Residual pain, hospitalization time, and the time to be able to sit up alone following surgery are influencing factors. The number of physical therapy sessions is directly related to an improvement in patient self-evaluation, but does not change the rate of return to work. The prior work regime does not affect the results.

The results of this study allow attending physicians to be able to identify patients at risk for a worse prognosis regarding return to their previous functions and, thus, subject them to more intensive rehabilitation with the objective of a more satisfactory outcome.

All authors declare no potential conflict of interest related to this article.

CONTRIBUTION OF THE AUTHORS: Each author made significant individual contributions to this manuscript. GSM and ALS were the main contributors to the preparation of the manuscript, managing the research project, and making the corrections suggested by the other authors and those requested by the editors. ALK and MLB helped to collect the data and select the most pertinent results. PGS analyzed the statistical data and collaborated in the development of the project. XSG coordinated the bibliographical research, the review of the manuscript, and resolved issues around content and how to present the results.

\section{REFERENCES}

1. Zaninelli EM, Graells XS, Néri OJ, Dau L. Avaliação epidemiológica das fraturas da coluna torácica e lombar de pacientes atendidos no Pronto-Socorro do Hospital do Trabalhador da UFPR de Curitiba - Paraná. Coluna/Columna. 2005;4(1):11-5.

2. Saboe LA, Reid DC, Davis LA, Warren SA, Grace MG. Spine trauma and associated injuries. JTrauma. 1991:31(1):43-8.

3. Tator $\mathrm{CH}$. Management of associated spine injuries in head-injured patients. In: Narayan RK, Wilberger JE, Povlishock JT, editors. Neurotrauma. 1st ed. New York: McGraw Hill; 1996. p. 1558.

4. Beaunoyer M, St-Vil D, Lallier M, Blanchard H. Abdominal injuries associated with thoraco-lumbar fractures after motor vehicle collision. J Pediatr Surg. 2001;36(5):760-2.

5. Cooper $C$, Dunham $C M$, Rodriguez A. Falls and major injuries are risk factors for thoracolumbar fractures: cognitive impairment and multiple injuries impede the detection of back pain and tenderness. JTrauma 1995;38(5):692-6.

6. Montesano PX, Benson BR. Fraturas e luxações da coluna vertebral. In: Rockwood CA Jr, Green DP, Bucholz RW, editores. Fraturas em adultos. $3^{a}$ ed. São Paulo: Manole; 1993. p. $1332-70$.

7. Chapman JR, Anderson PA. Thoracolumbar spine fractures with neurologic deficit. Orthop Clin North Am. 1994;25(4):595-612.

8. Leucht P, Fischer K, Muhr G, Mueller EJ. Epidemiology of traumatic spine fractures. Injury. 2009:40(2):166-72.

9. Mesard L, Carmody A, Mannarino E, Ruge D. Survival after spinal cord trauma: A life table analysis. Arch Neurol. 1978;35(2):78-83
10. Akmal $M$, Trivedi $R$, Sutcliffe J. Functional outcome in trauma patients with spinal injury. Spine (Phila Pa 1976). 2003;28(2):180-5

11. DeVivo MJ, Fine PR. Employment status of spinal cord injured patients 3 years after injury. Arch Phys Med Rehabil. 1982:63(5):200-3.

12. El Ghatit AZ. Variables associated with obtaining and sustaining employment among spinal cord injured males: a follow-up of 760 veterans. J Chronic Dis. 1978;31(5):363-9.

13. Burnham RS, Warren SA. Saboe LA, Davis LA, Russel GG, Reid DC. Factors predicting employment 1 year after traumatic spine fracture Spine. 1996;21(9):1066-71.

14. Baker SP, O'Neill B, Haddon W Jr, Long WB. The Injury Severity Score: a method for describing patients with multiple injuries and evaluating emergency care. J Trauma. 1974;14(3):187-96.

15. Yang Z, Lowe AJ, de la Harpe DE, Richardson MD. Factors that predict poor outcomes in patients with traumatic vertebral body fractures. Injury. 2010;41(2):226-30.

16. McLain RF. Functional outcomes after surgery for spinal fractures: return to work and activity. Spine. 2004;29(4):470-7.

17. MacKenzie EJ, Siegel JH, Shapiro S, Moody M, Smith RT. Functional recovery and medical costs of trauma: an analysis by type and severity of injury. JTrauma. 1988:28(3):281-97.

18. Burnham RS, Warren SA, Saboe LA, Davis LA, Russell GG, Reid DC. Factors predicting employment 1 year after traumatic spine fracture. Spine (Phila $\mathrm{Pa}$ 1976). 1996:21(9):1066-71.

19. McLain RF. Functional Outcomes After Surgery for Spinal Fractures: return to work and activity. Spine (Phila Pa 1976). 2004;29(4):4707. 